\title{
EVALUASI KESESUAIAN LAHAN UNTUK TANAMAN MANGGIS DAN POTENSI PENGEMBANGANNYA DI KECAMATAN PAUH KOTA PADANG
}

\section{Evaluation of Land Suitability and Its Potential for Development in Pauh District, Padang City}

\author{
Dyah Puspita Sari*, Ranti Novia, Juniarti \\ Jurusan Tanah, Fakultas Pertanian, Universitas Andalas, Kampus Limau Manis, Padang 25163 \\ *Penulis korespondensi: dyahpuspita21@gmail.com
}

\begin{abstract}
Pauh District was chosen as mangosteen plantation development centre in Padang City. This development should be based on the land suitability so that the mangosteen plant are able to grow according to the climate and soil conditions. This research was conducted in Pauh District, Padang City and Soil Science Laboratory Andalas University. This study used a survey method that consisted of preparation, pre-survey, the main surveiy, laboratory analysis, and data processing. Evaluation of land suitability was done with matching method which compare the characteristics of land suitability for mangosteen growth. The results of research showed that land suitability for mangosteen was classified into S3 (marginally suitable) with subclass S3nr for land unit SL1, SL2, SL3, SL4, SL7, SL8, SL9, SL11, SL15; subclass S3eh for land unit SL14; subclass S3nr,eh for land unit SL5 and SL10. Land unit SL6, SL12, SL13, and SL16 were classified into S2 (moderately suitable) with subclass S2wa,nr for land unit SL6 and SL16; subclass S2wa,rc,nr,eh for land unit SL12; subclass S2wa,rc,nr for land unit SL13. The limiting factors was common to each land unit were nutrient retention (nr) and erosion (eh). There are 3 villages (Lambung Bukit, Limau Manis, and South Limau Manis) in Pauh District which have the greatest potential to be developed as mangosteen plantation development areas with total area was 5,862.42 ha.
\end{abstract}

Keywords : land evaluation of suitability, mangosteen, Pauh district

\section{Pendahuluan}

Penentuan kesesuaian lahan dengan persyaratan tumbuhnya tanaman sangat diperlukan terutama dalam perencanaan pengembangan komoditas pertanian khususnya perkebunan seperti manggis. Hal ini penting karena untuk mengetahui potensi pengembangan tanaman perkebunan sangat diperlukan pewilayahan komoditas berdasarkan kelas kesesuaian lahan sehingga tanaman mampu tumbuh selaras dengan iklim dan kondisi lahan yang ada.

Menurut Sitorus (1985) salah satu dasar pertimbangan melakukan perencanaan secara menyeluruh adalah tersedianya informasi lingkungan fisik yang diperoleh dari kegiatan survei tanah yang diikuti dengan pengevaluasian lahan pada suatu daerah. Hasil evaluasi lahan memberikan informasi dan arahan penggunaan lahan sesuai dengan keperluan penggunaan seperti untuk perkebunan manggis.

Manggis merupakan salah satu tanaman buah tropis primadona di daerah Sumatera Barat. Tanaman manggis ini memiliki potensi dalam nilai ekonomis yaitu nilai ekspor. BPS dalam Statistik Tanaman Buah dan Sayuran mencatat ekspor manggis pada 2015 mencapai USD 17,2 juta dimana negara sasaran ekspor utama adalah Thailand, Malaysia, dan Hongkong. Nilai ekonomis ini mendorong pemerintah khususnya pemerintah Sumatera Barat untuk mengembangkan tanaman manggis sebagai upaya meningkatkan pendapatan dan 


\section{Jurnal Tanah dan Sumberdaya Lahan Vol 8 No 2: 317-326, 2021 e-ISSN:2549-9793, doi: 10.21776/ub.jts1.2021.008.2.2}

perekonomian masyarakat. Upaya pengembangan manggis ini masuk dalam salah satu kebijakan Gubernur Sumatera Barat melalui Nagari Mandiri Pangan.

Untuk mewujudkan Nagari Mandiri Pangan tersebut, maka Kecamatan Pauh memilih mengembangkan tanaman buahbuahan berupa manggis sebagai salah satu sektor pertanian yang mendukung perekonomian masyarakat. Pengembangan manggis di kecamatan ini juga didukung oleh Walikota Padang untuk menjadikan Kecamatan Pauh sebagai sentra perkebunan manggis di Kota Padang. Kecamatan Pauh memiliki lahan terlantar yang memiliki potensi untuk dimanfaatkan sebagai areal pertanian.

Namun pengembangan yang dilakukan ini, hanya berdasarkan dari penilaian potensi nilai ekonomis saja dan belum dilakukan evaluasi kesesuaian untuk tanaman manggis. Penelitian ini bertujuan untuk mendapatkan informasi kelas kesesuaian lahan dan potensi lahan untuk pengusahaan tanaman manggis di Kecamatan Pauh Kota Padang.

\section{Bahan dan Metode}

Penelitian ini dilaksanakan di Kecamatan Pauh Kota Padang dan kemudian dilanjutkan dengan analisis tanah di Laboratorium Tanah Fakultas Pertanian Universitas Andalas. Alat-alat utama yang digunakan adalah peta kerja, data curah hujan, GPS, buku Munsell soil-colour chart, Abney level. Bahan-bahan utama yang digunakan adalah kertas label, karet gelang, kantong plastik, serta bahan-bahan kimia yang diperlukan untuk analisis tanah di laboratorium.

Metoda yang digunakan dalam penelitian ini adalah metoda survei yang terdiri atas tahap persiapan, pra surveim survei utama, analisis tanah di laboratoriu, serta pengolahan data. Penentuan lokasi pengambilan sampe dilakukan secara Purposive Random Sampling berdasarkan satuan lahan pewakil. Pengamatan karakteristik tanah di lapangan dilakukan melalui pengamatan profil tanah. Profil tanah dibuat di setiap satuan lahan pewakil dengan ukuran $1,5 \mathrm{~m}$ (panjang) $\mathrm{x}$ $1,5 \mathrm{~m}$ (lebar) x 1,5 m (dalam). Sampel tanah yang diambil berupa sampel tanah satelit yaitu diambil dari tiap-tiap lapisan tanah pada lubang profil. Karakteristik fisik lahan yang diamati pada penelitian ini adalah kelerengan, drainase, batuan dipermukaan, dan singkapan batuan. Karakteristik tanah yang diamati pada penelitian ini adalah tekstur tanah (metoda ayakan dan pipet), kedalaman tanah, KTK (metoda pencucian $\mathrm{NH}_{4} \mathrm{OAc} \mathrm{pH}$ 7), kandungan kationkation basa dan kejenuhan basa, $\mathrm{pH} \mathrm{H}_{2} \mathrm{O}, \mathrm{Al}-$ dd, dan H-dd.

Penilaian kesesuaian lahan dilaksanakan dengan cara mencocokkan (matching) data tanah dan fisik lingkungan dengan tabel rating kesesuaian lahan yang telah disusun berdasarkan persyaratan penggunaan mencakup persyaratan tumbuh tanaman manggis (Tabel 1).

\section{Hasil dan Pembahasan}

\section{Kondisi umum wilayah penelitian}

Secara geografis Kecamatan Pauh terletak pada 0 58' LS dan 100'21'11'" BT dengan luas 16.079,78 ha yang terletak pada ketinggian 25 1841 meter di atas permukaan laut (mdpl) dengan suhu $22,0^{\circ} \mathrm{C}-31,7^{\circ} \mathrm{C}$ dan curah hujan $2087 \mathrm{~mm}$ tahun $^{-1}$. Secara administrasi Kecamatan Pauh terdiri atas 9 kelurahan yaitu Pisang, Binuang Kampung Dalam, Koto Luar, Cupak Tangah, Piai Tangah, Kapalo Koto, Lambung Bukit, Limau Manis, Limau Manis Selatan. Kecamatan ini memiliki batas wilayah sebelah Utara berbatasan dengan Kecamatan Koto Tangah, sebelah Selatan berbatasan dengan Kecamatan Lubuk Kilangan dan Lubuk Begalung, sebelah Timur berbatasan dengan Kabupaten Solok, dan sebelah Barat berbatasan dengan Kecamatan Kuranji dan Padang Timur (Badan Pusat Statistik, 2017). Sebaran jenis tanah di lokasi penelitian berdasarkan Peta Satuan Lahan dan Tanah Lembar Solok (0815) bersumber dari Pusat Penelitian Tanah dan Agroklimat tahun 1990 skala $1: 250.000$. Ordo tanah yang ditemukan di lapangan adalah Ultisol dan Inceptisol (Tabel 2). Menurut Fiantis (2015), Ultisol adalah tanah masam yang mempunyai basa rendah dan terjadi akumulasi liat di horizon bawah. Terdapat di daerah hutan tropis basah, biasanya pada landscape tua dan stabil. Proses pembentukan Ultisol adalah pelapukan dan akumulasi mineral liat di horizon B. Epipedon penciri adalah okrik atau umbrik dan di horizon bawah dijumpai argilik atau kandik yang lebih masam dari horizon atas. 
Jurnal Tanah dan Sumberdaya Lahan Vol 8 No 2: 317-326, 2021

e-ISSN:2549-9793, doi: 10.21776/ub.jts1.2021.008.2.2

Tabel 1. Kriteria persyaratan tumbuh tanaman manggis.

\begin{tabular}{|c|c|c|c|c|}
\hline \multirow{2}{*}{$\begin{array}{l}\text { Persyaratan } \\
\text { penggunaan/karakteristik } \\
\text { lahan }\end{array}$} & \multicolumn{4}{|c|}{ Kelas Kesesuaian Lahan } \\
\hline & S1 & S2 & S3 & $\mathbf{N}$ \\
\hline Temperatur (tc) & $18-25$ & $25-30$ & $30-35$ & $>35$ \\
\hline Temperatur rerata $\left({ }^{\circ} \mathrm{C}\right)$ & & $15-18$ & $10-15$ & $<10$ \\
\hline \multicolumn{5}{|l|}{ Ketersediaan air (wa) } \\
\hline \multirow[t]{2}{*}{ Curah Hujan (mm) } & $1000-2000$ & $500-1000$ & $250-500$ & $<250$ \\
\hline & & $2000-3000$ & $3000-40000$ & $>4000$ \\
\hline Ketersediaan oksigen (oa) & Sedang & Agak & Terhambat, & Sangat \\
\hline Drainase & & terhambat & agak cepat & $\begin{array}{c}\text { terhambat, } \\
\text { cepat }\end{array}$ \\
\hline \multicolumn{5}{|l|}{ Media perakaran (rc) } \\
\hline Tekstur & $\begin{array}{l}\text { Halus, agak } \\
\text { halus, } \\
\text { sedang }\end{array}$ & & Agak kasar & Kasar \\
\hline Kedalaman tanah $(\mathrm{cm})$ & $>100$ & $75-100$ & $50-75$ & $<50$ \\
\hline \multicolumn{5}{|l|}{ Retensi hara (nr) } \\
\hline KTK liat (cmol) & $>16$ & $<16$ & & \\
\hline Kejenuhan basa (\%) & $>35$ & $<35$ & & \\
\hline \multirow[t]{2}{*}{$\mathrm{pH} \mathrm{H} \mathrm{H}_{2} \mathrm{O}$} & $5,5-7,8$ & $5,0-5,5$ & $<5,0$ & \\
\hline & & $7,8-8,0$ & $>8,0$ & \\
\hline C-Organik ( $\%)$ & $>1,2$ & $0,8-1,2$ & $<0,8$ & \\
\hline \multicolumn{5}{|l|}{ Bahaya Erosi (eh) } \\
\hline Lereng $(\%)$ & $<8$ & $8-16$ & $16-30$ & $>30$ \\
\hline Bahaya erosi & $\begin{array}{l}\text { Sangat } \\
\text { rendah }\end{array}$ & $\begin{array}{c}\text { Rendah - } \\
\text { sedang }\end{array}$ & Berat & Sangat berat \\
\hline
\end{tabular}

Sumber: Djaenudin et al. (2011).

Tabel 2. Satuan lahan di Kecamatan Pauh Kota Padang.

\begin{tabular}{lcccc}
\hline Satuan Lahan & Jenis Tanah & Penggunaan Lahan & Lereng (\%) & Kode \\
\hline Incept.H.A & Inceptisol & Hutan & $0-8 \%$ (Datar) & SL1 \\
Incept.H.B & Inceptisol & Hutan & $8-15 \%$ (Landai) & SL2 \\
Incept.K.A & Inceptisol & Kebun Campuran & $0-8 \%$ (Datar) & SL3 \\
Incept.K.B & Inceptisol & Kebun Campuran & $8-15 \%$ (Landai) & SL4 \\
Incept.K.C & Inceptisol & Kebun Campuran & $15-25 \%$ (Agak Curam) & SL5 \\
Incept.L.A & Inceptisol & Ladang & $0-8 \%$ (Datar) & SL6 \\
Incept.L.B & Inceptisol & Ladang & $8-15 \%$ (Landai) & SL7 \\
Incept.SB.A & Inceptisol & Semak Belukar & $0-8 \%$ (Datar) & SL8 \\
Incept.SB.B & Inceptisol & Semak Belukar & $8-15 \%$ (Landai) & SL9 \\
Incept.SB.C & Inceptisol & Semak Belukar & $15-25 \%$ (Agak Curam) & SL10 \\
Ult.H.A & Ultisol & Hutan & $0-8 \%$ (Datar) & SL11 \\
Ult.H.B & Ultisol & Hutan & $8-15 \%$ (Agak Curam) & SL12 \\
Ult.K.A & Ultisol & Kebun Campuran & $0-8 \%$ (Datar) & SL13 \\
Ult.K.C & Ultisol & Kebun Campuran & $15-25 \%$ (Agak Curam) & SL14 \\
Ult.SB.B & Ultisol & Semak Belukar & $8-15 \%$ (Landai) & SL15 \\
Ult. L. A & Ultisol & Ladang & $0-8 \%$ (Datar) & SL16 \\
\hline
\end{tabular}




\section{Jurnal Tanah dan Sumberdaya Lahan Vol 8 No 2: 317-326, 2021 \\ e-ISSN:2549-9793, doi: 10.21776/ub.jts1.2021.008.2.2}

Ultisol mempunyai keseburan alami yang relatif rendah, berwarna kuning atau kemerahan akibat pembentukan Fe sedangkan Inceptisol adalah tanah yang masih tergolong muda dengan perkembangan profil tanah lebih baik bila dibandingkan dengan Entisols. Epipedon penciri antara lain umbrik ataupun okrik. Horizon bawah adalah kambik yang dicirikan dengan adanya perubahan warna atau struktur tanah.

Pengambilan sampel dilakukan pada kelerengan $0-8 \%, 8-15 \%$, dan $15-25 \%$. Jika dimasukkan kedalam kriteria kesesuaian lahan untuk tanaman manggis berdasarkan kelas kesesuaian lahan pusat penelitian dan pengembangan agroklimat Bogor (2003), lereng dengan kemiringan $<8 \%$ termasuk dalam kelas sangat sesuai (S1), lereng dengan kemiringan 8 $15 \%$ termasuk dalam kelas cukup sesuai (S2), dan lereng dengan kemirigan $15-25 \%$ termasuk sesuai marjinal (S3).

\section{Iklim daerah penelitian}

Berdasarkan data curah hujan yang bersumber dari BPSDA Sumbar dalam kurun waktu 10 tahun (2007-2016), Kecamatan Pauh memiliki rata-rata curah hujan tahunan mencapai 2087 mm tahun ${ }^{-1}$ yang apabila dimasukkan kedalam kriteria kesesuaian lahan untuk tanaman manggis termasuk dalam kelas cukup sesuai (S2). Tipe iklim Kecamatan Pauh menurut klasifikasi Schmidt dan Ferguson termasuk tipe iklim A (sangat basah) $(0-14,33 \%)$ dengan nilai $\mathrm{Q}$ yaitu $2,59 \%$ dengan rata-rata jumlah bulan kering di Kecamatan Pauh selama periode pengamatan 10 tahun yaitu 0,3 dan rata-rata bulan basah 11,6.

\section{Sifat kimia tanah}

\section{pH tanah dan Al-dd tanah}

Semua satuan lahan bereaksi masam (Tabel 3). Hal ini menunjukkan kandungan kemasaman didalam tanah tinggi akibat adanya pencucian yang intensif akibat curah hujan yang tinggi. Penelitian Hermansah et al. (2008) menunjukkan bahwa $\mathrm{pH}$ tanah di daerah Padang berada dalam kategori masam karena curah hujan rata-rata yang mencapai $850 \mathrm{~mm}$ bulan $^{-1}$. Menurut Hakim (1986), kemasaman tanah merupakan hal yang biasa terjadi diwilayah dengan curah hujan tinggi. Hal ini karena tercucinya basa-basa dari kompleks jerapan dan hilang melalui air drainase dan menyisakan $\mathrm{Al}$ dan $\mathrm{H}$ sebagai kation dominan yang menyebabkan tanah bereaksi masam. Pada hasil analisis, didapatkan beberapa satuan lahan yang mengandung logam aluminium yang merupakan salah satu sumber kemasaman tanah. Dalam keadaan masam, Al menjadi sangat larut dalam bentuk ion $\mathrm{Al}^{3+}$ dan hidroksida Al. kedua ion ini mudah terjerap koloid liat dan berada dalam keadaan seimbang dengan $\mathrm{Al}$ dalam larutan tanah. $\mathrm{Al}$ mudah terhidrolisis sehingga $\mathrm{Al}$ menyumbangkan ion $\mathrm{H}$ yang merupakan sumber kemasaman utama tanah. Menurut Hardjowigeno (2010), nilai pH 4,5 - 5,5 bereaksi masam sehingga apabila dihubungkan dengan kriteria kesesuaian lahan untuk tanaman manggis maka termasuk dalam kelas sangat sesuai (S1) hingga cukup sesuai (S2).

\section{C-organik tanah}

Hasil analisis nilai persentase kandungan Corganik sangat bervariasi mulai dari kriteria sedang dengan nilai 2,62\% hingga kriteria tinggi dengan nilai 3,13\% (Tabel 3). Kandungan Corganik dipengaruhi oleh kandungan bahan organik. Karbon merupakan bahan organik yang utama. Menurut Nurul (2005), bahan organik dalam tanah dipengaruhi oleh arus akumulasi bahan asli dan proses dekomposisi dan humifikasi yang dipengaruhi oleh iklim dan vegetasi.

Dekomposisi bahan organik didalam tanah menghasilkan $\mathrm{CO}_{2}, \mathrm{CO}_{3}, \mathrm{HCO}_{3}, \mathrm{C}$, dan $\mathrm{CH}_{4}$ yang menyebabkan terjadinya peningkatan karbon didalam tanah (Emalinda et al., 2005) Dari hasil analisis ini apabila dikaitkan dengan kriteria kesesuaian lahan untuk tanaman manggis maka termasuk kelas sangat sesuai (S1) untuk setiap satuan lahan sebab kandungan corganik tanah pada tiap satuan lahan melebihi $1,2 \%$.

Kapasitas tukar kation dan kandungan kation basa

Kapasitas tukar kation suatu tanah didefinisikan sebagai suatu kemampuan koloid tanah dalam menjerap dan mempertukarkan kation. Tingginya nilai KTK tanah dipengaruhi oleh sifat dan ciri tanah itu sendiri, seperti $\mathrm{pH}$ tanah, tekstur tanah, jumlah liat, jenis mineral liat, bahan organik, pengapuran, dan pemupukan (Hakim et al., 1986). 
Jurnal Tanah dan Sumberdaya Lahan Vol 8 No 2: 317-326, 2021

e-ISSN:2549-9793, doi: 10.21776/ub.jts1.2021.008.2.2

Tabel 3. Sifat Kimia Tanah di Kecamatan Pauh. Kota Padang.

\begin{tabular}{|c|c|c|c|c|c|c|c|c|c|c|c|}
\hline \multirow{2}{*}{$\begin{array}{l}\text { Satuan } \\
\text { Lahan }\end{array}$} & \multicolumn{11}{|c|}{ Sifat Kimia Tanah } \\
\hline & pH H$~_{2} \mathrm{O}$ & $\begin{array}{c}\text { Al-dd } \\
\left(\mathrm{me} 100 \mathrm{~g}^{-1}\right)\end{array}$ & $\begin{array}{c}\text { H-dd } \\
\left(\left(\text { me } 100 g^{-1}\right)\right.\end{array}$ & $\begin{array}{c}\text { C- } \\
\text { organik } \\
(\%)\end{array}$ & $\begin{array}{c}\text { Bahan } \\
\text { Organik } \\
(\%)\end{array}$ & $\begin{array}{c}\text { KTK } \\
\left(m e 100 g^{-1}\right)\end{array}$ & $\begin{array}{c}\text { K-dd } \\
\left(m e 100 g^{-1}\right)\end{array}$ & $\begin{array}{c}\text { Na-dd } \\
\left({\left.\mathrm{me} 100 \mathrm{~g}^{-1}\right)}\right.\end{array}$ & $\begin{array}{c}\text { Mg-dd } \\
\left({\left.\text { me } 100 \mathrm{~g}^{-1}\right)}^{-1}\right.\end{array}$ & $\begin{array}{c}\text { Ca-dd } \\
\left({\left.\mathrm{me} 100 \mathrm{~g}^{-1}\right)}^{-1}\right.\end{array}$ & $\begin{array}{c}\text { Kejenuhan } \\
\text { Basa } \\
(\%)\end{array}$ \\
\hline SL1 & $4.83^{\mathrm{M}}$ & 1.12 & 0.45 & $2.81^{\mathrm{S}}$ & 4.83 & 9.93 & $0.29^{\mathrm{R}}$ & $0.20^{\mathrm{R}}$ & $0.83^{\mathrm{R}}$ & $0.34^{\mathrm{SR}}$ & $16.71^{\mathrm{SR}}$ \\
\hline SL2 & $4.69^{\mathrm{M}}$ & tu & 0.58 & $2.9^{\mathrm{S}}$ & 4.98 & 9.58 & $0.33^{\mathrm{S}}$ & $0.23^{\mathrm{R}}$ & $0.85^{\mathrm{R}}$ & $0.4^{\mathrm{SR}}$ & $18.89^{\mathrm{SR}}$ \\
\hline SL3 & $4.54^{\mathrm{M}}$ & tu & 0.22 & $2.85^{\mathrm{S}}$ & 4.90 & 9.78 & $0.34^{\mathrm{S}}$ & $0.24^{\mathrm{R}}$ & $0.79^{\mathrm{R}}$ & $0.4^{\mathrm{SR}}$ & $18.09^{\mathrm{SR}}$ \\
\hline SL4 & $4.77^{\mathrm{M}}$ & tu & 0.22 & $2.85^{\mathrm{S}}$ & 4.90 & 9.96 & $0.34^{\mathrm{S}}$ & $0.28^{\mathrm{R}}$ & $0.76^{\mathrm{R}}$ & $0.42^{\mathrm{SR}}$ & $18.07^{\mathrm{SR}}$ \\
\hline SL5 & $4.81^{\mathrm{M}}$ & tu & 0.11 & $2.85^{\mathrm{S}}$ & 4.90 & 10.23 & $0.33^{\mathrm{S}}$ & $0.29^{\mathrm{R}}$ & $0.78^{\mathrm{R}}$ & $0.42^{\mathrm{SR}}$ & $17.79^{\mathrm{SR}}$ \\
\hline SL6 & $5.34^{\mathrm{M}}$ & 0.51 & 0.62 & $3.13^{\mathrm{T}}$ & 5.39 & 9.04 & $0.37^{\mathrm{S}}$ & $0.33^{\mathrm{s}}$ & $0.79^{\mathrm{R}}$ & $0.41^{\mathrm{SR}}$ & $21.01^{\mathrm{R}}$ \\
\hline SL7 & $5.21^{\mathrm{M}}$ & 0.75 & 0.54 & $2.69^{\mathrm{S}}$ & 4.64 & 9.95 & $0.29^{\mathrm{R}}$ & $0.28^{\mathrm{R}}$ & $0.63^{\mathrm{R}}$ & $0.39^{\mathrm{SR}}$ & $15.97^{\mathrm{SR}}$ \\
\hline SL8 & $4.87^{\mathrm{M}}$ & tu & 1.21 & $3.00^{\mathrm{S}}$ & 5.16 & 12.91 & $0.39^{\mathrm{S}}$ & $0.37^{\mathrm{S}}$ & $0.76^{\mathrm{R}}$ & $0.47^{\mathrm{SR}}$ & $15.41^{\mathrm{SR}}$ \\
\hline SL9 & $5.02^{\mathrm{M}}$ & tu & 1.13 & $2.83^{\mathrm{S}}$ & 4.88 & 10.79 & $0.33^{\mathrm{S}}$ & $0.31^{\mathrm{S}}$ & $0.74^{\mathrm{R}}$ & $0.46^{\mathrm{SR}}$ & $17.05^{\mathrm{SR}}$ \\
\hline SL10 & $4.57^{\mathrm{M}}$ & 0.33 & 0.99 & $2.75^{\mathrm{S}}$ & 4.73 & 6.93 & $0.21^{\mathrm{R}}$ & $0.32^{\mathrm{S}}$ & $0.63^{\mathrm{R}}$ & $0.41^{\mathrm{SR}}$ & $22.65^{\mathrm{R}}$ \\
\hline SL11 & $5.15^{\mathrm{M}}$ & 0.45 & 0.33 & $2.83^{\mathrm{S}}$ & 4.88 & 12.23 & $0.36^{\mathrm{S}}$ & $0.32^{\mathrm{S}}$ & $0.73^{\mathrm{R}}$ & $0.44^{\mathrm{SR}}$ & $15.12^{\mathrm{SR}}$ \\
\hline SL12 & $4.68^{\mathrm{M}}$ & 0.96 & 0.64 & $2.67^{\mathrm{S}}$ & 4.60 & 9.00 & $0.32^{\mathrm{S}}$ & $0.28^{\mathrm{R}}$ & $0.78^{\mathrm{R}}$ & $0.46^{\mathrm{SR}}$ & $20.44^{\mathrm{R}}$ \\
\hline SL13 & $4.59^{\mathrm{M}}$ & tu & 0.73 & $2.73^{\mathrm{S}}$ & 4.70 & 7.97 & $0.33^{\mathrm{S}}$ & $0.32^{\mathrm{S}}$ & $0.77^{\mathrm{R}}$ & $0.39^{\mathrm{SR}}$ & $22.71^{\mathrm{R}}$ \\
\hline SL14 & $5.24^{\mathrm{M}}$ & tu & 0.32 & $2.77^{\mathrm{S}}$ & 4.77 & 9.61 & $0.37^{\mathrm{S}}$ & $0.34^{\mathrm{S}}$ & $0.83^{\mathrm{R}}$ & $0.45^{\mathrm{SR}}$ & $20.70^{\mathrm{R}}$ \\
\hline SL15 & $4.49^{\mathrm{SM}}$ & 0.99 & 0.66 & $2.76^{\mathrm{S}}$ & 4.75 & 8.17 & $0.36^{\mathrm{S}}$ & $0.34^{\mathrm{S}}$ & $0.74^{\mathrm{R}}$ & $0.5^{\mathrm{SR}}$ & $23.74^{\mathrm{R}}$ \\
\hline SL16 & $4.57^{\mathrm{M}}$ & tu & 0.45 & $2.85^{\mathrm{S}}$ & 4.90 & 9.23 & $0.35^{\mathrm{S}}$ & $0.35^{\mathrm{S}}$ & $0.73^{\mathrm{R}}$ & $0.43^{\mathrm{SR}}$ & $20.15^{\mathrm{R}}$ \\
\hline
\end{tabular}

Keterangan: $\mathrm{M}=$ Masam; $\mathrm{SM}=$ Sangat Masam; $\mathrm{S}=$ Sedang, $\mathrm{R}=$ Rendah, $\mathrm{SR}=$ Sangat Rendah; tu = tidak terukur 


\section{Jurnal Tanah dan Sumberdaya Lahan Vol 8 No 2: 317-326, 2021 e-ISSN:2549-9793, doi: 10.21776/ub.jts1.2021.008.2.2}

Dari hasil analisis, didapatkan nilai KTK tanah berada pada kriteria rendah dengan nila 6,9712,97 me $100 \mathrm{~g}^{-1}$ tanah (Tabel 3). Rendahnya nilai KTK pada tanah karena ultisol merupakan tanah yang didominasi oleh fraksi oksida-hidrat $\mathrm{Al}$ dan Fe biasanya memiliki muatan negatif yang rendah pada permukaan koloid (Sposito, 2010), sehingga nilai KTK tanah biasanya rendah.

Kejenuhan basa merupakan hasil perbandingan antara kadar kation basa dengan nilai KTK tanah. Kation-kation yang terdapat dalam kompleks jerapan koloid dibedakan menjadi kation-kation yang bersifat basa dan kation yang bersifat masam. Kation basa pada umumnya merupakan unsur hara yang diperlukan oleh tanaman. Dari Tabel 3, terlihat bahwa keseluruhan satuan lahan memiliki kejenuhan basa yang sangat rendah hingga rendah yaitu berkisar $15,12 \%-22,74 \%$. Hal ini memungkinkan jumlah kation basa yang rendah telah hilang akibat terjadinya proses pencucian oleh curah hujan yang tinggi. Hardjowigeno (2010) menyatakan bahwa kejenuhan basa menunjukkan tingkat pencucian basa-basa dari tanah. Rendahnya Ca-dd dalam tanah karena ion $\mathrm{Ca}$ merupakan ion divalen yang mudah digantikan oleh ion monovalen pada koloid tanah. Ion divalen yang ada pada larutan tanah akan hilang dibawa oleh erosi dan tercuci (Hermansah et al., 2008). Dari seluruh satuan lahan, jika dihubungkan nilai KTK dengan kriteria kesesuaian lahan untuk tanaman manggis, maka didapatkan kelas cukup sesuai (S2) untuk seluruh satuan lahan, sedangkan untuk kejenuhan basa didapatkan kelas cukup sesuai (S2) dan sesuai marjinal (S3).

\section{Tekstur tanah}

Tekstur tanah merupakan perbandingan relatif fraksi pasir, debu, dan liat dalam suatu massa tanah. Berdasarkan hasil analisis tanah yang telah dilakukan, maka didapatkan hasil tekstur tanah pada setiap satuan lahan adalah liat (Tabel 4). Semakin bertambah kedalaman tanah maka semakin meningkat kandungan liat pada setiap satuan lahan. Meningkatnya kandungan liat pada setiap kedalaman ini karena ordo tanah yang umum di Kecamatan Pauh yaitu Ultisol. Pada ordo Ultisol terjadi penumpukan liat di horizon bawah (horizon argilik), bersifat asam, dan kejenuhan basa kurang dari $35 \%$
(Hardjowigeno, 2010). Tingginya fraksi liat dalam tanah dipengaruhi oleh bahan induk tanah. Bahan induk tanah berupa bahan volkan andesitik - basaltik dan bahan batu kapur cenderung akan mempunyai kandungan fraksi liat yang tinggi (Prasetyo et al., 2005). Hal ini didukung oleh Hermon dan Triyatno (2005) bahwa Kota Padang memiliki bahan induk yang berupa andesit dan tuff yang berselingan dan/atau andesit sebagai inklusi di dalam tuff. Untuk kriteria kesesuaian lahan tanaman manggis, sebaran tekstur tanah dapat dimasukkan pada kelas sangat sesuai (S1) untuk semua daerah penelitian.

Tabel 4. Tekstur tanah di Kecamatan Pauh, Kota Padang.

\begin{tabular}{ccccc}
\hline $\begin{array}{c}\text { Satuan } \\
\text { Lahan }\end{array}$ & \multicolumn{4}{c}{ Tekstur Tanah } \\
\cline { 2 - 5 } & $\begin{array}{c}\text { \% } \\
\text { Pasir }\end{array}$ & $\begin{array}{c}\text { \% } \\
\text { Debu }\end{array}$ & $\begin{array}{c}\text { \% } \\
\text { Liat }\end{array}$ & Tekstur \\
\hline 1 & 10.02 & 4.43 & 85.55 & liat \\
2 & 9.87 & 13.33 & 76.8 & liat \\
3 & 9.87 & 13.33 & 76.8 & liat \\
4 & 9.87 & 13.33 & 76.8 & liat \\
5 & 9.87 & 13.33 & 76.8 & liat \\
6 & 11.62 & 3.67 & 84.71 & liat \\
7 & 9.91 & 9.26 & 80.83 & liat \\
8 & 7.3 & 6.02 & 86.68 & liat \\
9 & 6.6 & 4.58 & 88.82 & liat \\
10 & 13.61 & 4.63 & 81.76 & liat \\
11 & 13.64 & 6.23 & 80.13 & liat \\
12 & 14.35 & 30.34 & 55.31 & liat \\
13 & 16.54 & 20.7 & 62.76 & liat \\
14 & 12.96 & 7.02 & 80.02 & liat \\
15 & 8.89 & 8.93 & 82.18 & liat \\
16 & 10.6 & 14.87 & 74.53 & liat \\
\hline
\end{tabular}

\section{Evaluasi kesesuaian lahan}

Evaluasi kesesuaian lahan dilakukan hanya pada lahan-lahan yang potensial untuk pertanian sedangkan kawasan khusus seperti hutan lindung tidak ikut dinilai. Menurut Djaenudin et al. (2011) karakteristik lahan yang digunakan dalam penelitian ini adalah karakteristik lahan yang dapat mewaliki kualitas lahan seperti, ketersedian air (wa), media perakaran (rc), retensi hara (nr), bahaya erosi (eh).

Menurut Rayes (2007) metode matching untuk nilai kesesuaian lahan adalah membandingkan kelas kesesuaian lahan didasarkan pada nilai terendah (terberat) sebagai 


\section{Jurnal Tanah dan Sumberdaya Lahan Vol 8 No 2: 317-326, 2021 e-ISSN:2549-9793, doi: 10.21776/ub.jts1.2021.008.2.2}

faktor pembatas dalam evaluasi kesesuaian lahan. Pada metode faktor pembatas setiap sifatsifat lahan atau kualitas lahan disusun berurutan mulai yang terbaik (memiliki pembatas paling rendah) hingga yang terburuk atau yang penghambatnya, sehingga faktor pembatas terkecil untuk kelas terbaik dan faktor pembatas terbesar untuk kelas terburuk.

Dari hasil analisis dan pengamatan terhadap kualitas dan karakteristik lahan untuk tanaman manggis pada masing-masing satuan lahan, maka didapatkan kesesuaian lahan aktual yang dapat dilihat pada Tabel 5 dan Gambar 1 .

Tabel 5. Kesesuaian lahan untuk tanaman manggis.

\begin{tabular}{ccc}
\hline Satuan & \multicolumn{2}{c}{ Kesesuaian Lahan } \\
\cline { 2 - 3 } Lahan & Aktual & Potensial \\
\hline SL1 & S3nr & S2wa,nr \\
SL2 & S3nr & S2wa,nr \\
SL3 & S3nr & S2wa,nr \\
SL4 & S3nr & S2wa,nr \\
SL5 & S3nr,eh & S2wa,nr,eh \\
SL6 & S2wa,nr & S2wa \\
SL7 & S3nr & S2wa,nr \\
SL8 & S3nr & S2wa,nr \\
SL9 & S3nr & S2wa,nr \\
SL10 & S3nr,eh & S2wa,nr,eh \\
SL11 & S3nr & S2wa,nr \\
SL12 & S2wa,rc,nr,eh & S2wa,rc \\
SL13 & S2wa,rc,nr & S2wa,rc \\
SL14 & S3eh & S2wa,nr,eh \\
SL15 & S3nr & S2wa,nr \\
SL16 & S2wa,nr & S2wa \\
\hline
\end{tabular}

Menurut Sastrohartono (2011) kesesuaian lahan aktual adalah kesesuain lahan yang dihasilkan berdasarkan data yang ada belum mempertimbangkan asumsi atau usaha perbaikan dan tingkat pengelolaan yang ada.

Setelah dilakukan kesesuaian lahan pada masing-masing satuan lahan maka didapatkan adalah SL1, SL2, SL3, SL4, SL5, SL7, SL8, SL 9, SL10, SL11, SL14, SL 15 termasuk kelas sesuai marjinal (S3) dengan sub kelas S3nr dengan faktor pembatas retensi hara untuk SL1, SL2, SL3, SL4, SL7, SL8, SL9, SL11, SL 15, sub kelas S3nr,eh dengan faktor pembatas retensi hara dan bahaya erosi untuk SL5 dan SL10, subkelas S3eh dengan faktor pembatas bahaya erosi untuk SL14. Pada satuan lahan SL6, SL12, SL13, dan SL16 didapatkan kelas kesesuaian cukup sesuai (S2) dengan subkelas S2wa,nr dengan faktor pembatas ketersediaan air dan retensi hara untuk SL6 dan SL16, S2wa,rc,nr,eh dengan faktor pembatas ketersediaan air, media perakaran, retensi hara, dan bahaya erosi untuk SL12, dan S2wa,rc,nr dengan faktor pembatas ketersediaan air, media perakaran, dan retensi hara untuk SL13.

\section{Tindakan pengelolaan}

Dari hasil kelas kesesuaian lahan aktual, dapat dilihat bahwa faktor pembatas yang terdapat pada lahan adalah retensi hara (nr) dan bahaya erosi/lereng (eh). Faktor pembatas yang ada pada lahan dapat diatasi dengan melakukan upaya-upaya perbaikan agar tanaman manggis dapat berproduksi dengan optimal.

Perbaikan pada faktor pembatas lereng dapat dilakukan dengan menanam sesuai dengan kaedah konservasi seperti penanaman dalam strip (strip cropping) adalah suatu sistem bercocok tanam dengan beberapa jenis tanaman dalam strip strip yang berselang seling pada lahan dan disusun memotong lereng atau menurut garis kontur. Menurut Nurdin (2012), penanaman dalam strip mampu menekan aliran permukaan dan erosi tanah hingga 99\% dibandingkan dengan penanaman tanpa perlakuan konservasi. Hal ini karena meningkatnya penyerapan air oleh tanah dan menghindari erosi tanah. Perbaikan pada faktor pembatas retensi hara adalah dengan menambahkan bahan organik dan pupuk sebagai tambahan unsur hara didalam tanah. Penambahan bahan organik akan meningkatkan muatan negatif sehingga akan meningkatkan kapasitas pertukaran kation (KPK). Bahan organik memberikan konstribusi yang nyata terhadap KPK tanah. Sekitar 20-70\% kapasitas pertukaran tanah pada umumnya bersumber pada koloid humus (contoh: Molisol), sehingga terdapat korelasi antara bahan organik dengan KPK tanah (Stevenson, 1994). Bahan organik yang ditambahkan dapat berupa pupuk organik seperti pupuk kompos, pupuk hijau, ataupun pupuk kandang. Menurut Putra dan Jalil (2015), penambahan bahan organik sebesar $20 \mathrm{t} \mathrm{ha}^{-1}$ pada Ultisol sangat nyata mampu meningkatkan $\mathrm{P}$ tersedia dan bakteri pelarut fosfat, serta nyata meningkatkan $\mathrm{pH}$ dan $\mathrm{C}$ organik tanah. 
Jurnal Tanah dan Sumberdaya Lahan Vol 8 No 2: 317-326, 2021

e-ISSN:2549-9793, doi: 10.21776/ub.jts1.2021.008.2.2

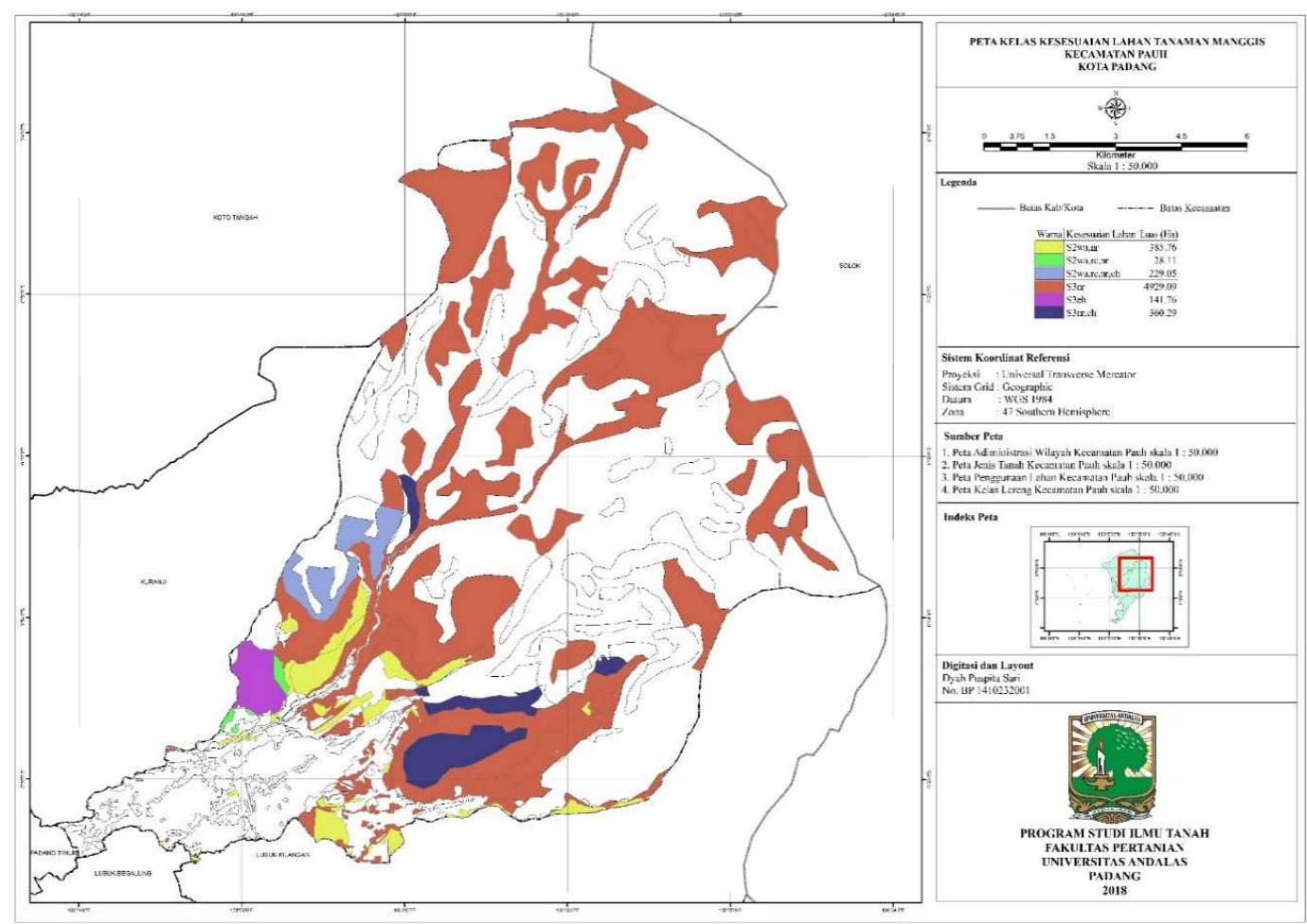

Gambar 1. Peta kesesuaian lahan untuk tanaman manggis di Kecamatan Pauh, Kota Padang.

\section{Potensi pengembangan manggis}

Kecamatan Pauh terdiri atas 9 kelurahan yaitu Pisang, Binuang Kampung Dalam, Koto Luar, Cupak Tangah, Piai Tangah, Kapalo Koto, Lambung Bukit, Limau Manis, Limau Manis Selatan dengan luas total $16.079,78$ ha. Dari luasan total terdapat setidaknya $36,05 \%$ wilayah dengan luas 5862,42 ha yang berpotensi untuk dikembangkan sebagai wilayah penanaman tanaman manggis (Gambar 2). Dari 9 kelurahan yang ada terdapat 3 kelurahan yang memiliki potensi paling besar untuk dikembangkan yaitu di Kelurahan Lambung Bukit sebesar 18\% dengan luas 2896,98 ha, Kelurahan Limau Manis sebesar 9,88\% dengan luas 1588,07 ha, dan Kelurahan Limau Manis Selatan sebesar 7,97\% dengan luas 1281,64 ha.

\section{Kesimpulan}

Pada satuan lahan SL1, SL2, SL3, SL4, SL5, SL7, SL8, SL 9, SL10, SL11, SL14, SL 15 termasuk kelas sesuai marjinal (S3) dengan sub kelas S3nr dengan faktor pembatas retensi hara untuk SL1,
SL2, SL3, SL4, SL7, SL8, SL9, SL11, SL 15, sub kelas S3nr,eh dengan faktor pembatas retensi hara dan bahaya erosi untuk SL5 dan SL10, subkelas S3eh dengan faktor pembatas bahaya erosi untuk SL14. Pada satuan lahan SL6, SL12, SL13, dan SL16 didapatkan kelas kesesuaian cukup sesuai (S2) dengan subkelas S2wa,nr dengan faktor pembatas ketersediaan air dan retensi hara untuk SL6 dan SL16, S2wa,rc,nr,eh dengan faktor pembatas ketersediaan air, media perakaran, retensi hara, dan bahaya erosi untuk SL12, dan S2wa,rc,nr dengan faktor pembatas ketersediaan hara, media perakaran, dan retensi hara untuk SL13. Faktor pembatas yang umum pada masing-masing lahan adalah retensi hara (nr) dan bahaya erosi/lereng (eh). Terdapat $36,05 \%$ wilayah dengan luas 5862,42 ha yang berpotensi untuk dikembangkan sebagai wilayah penanaman tanaman manggis. Ada 3 kelurahan yang memiliki potensi paling besar untuk dikembangkan yaitu di Kelurahan Lambung Bukit sebesar 18\% dengan luas 2896,98 ha, Kelurahan Limau Manis sebesar 9,88\% dengan luas 1588,07 ha, dan Kelurahan Limau Manis Selatan sebesar 7,97\% dengan luas 1281,64 ha. 
Jurnal Tanah dan Sumberdaya Lahan Vol 8 No 2: 317-326, 2021

e-ISSN:2549-9793, doi: 10.21776/ub.jts1.2021.008.2.2

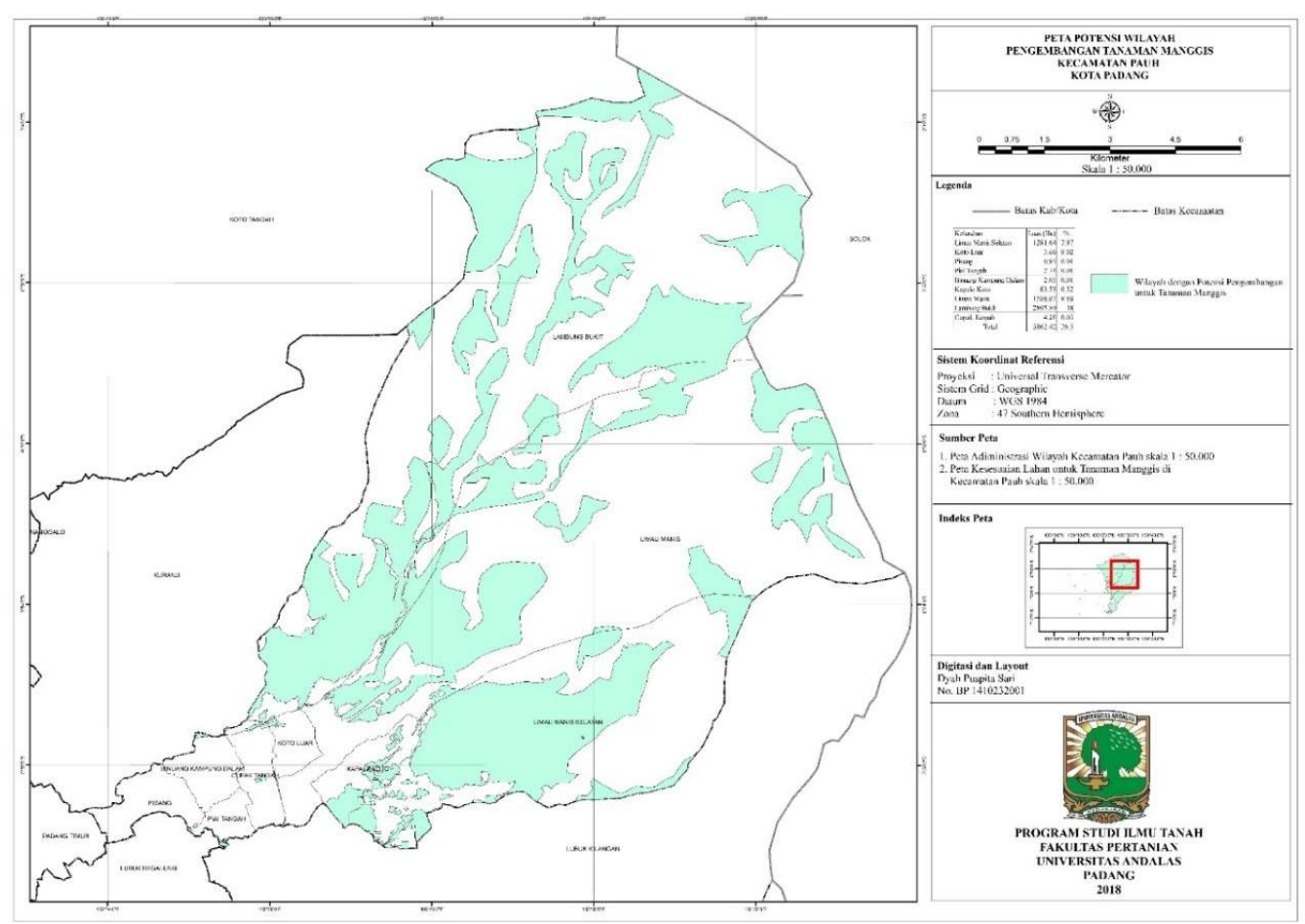

Gambar 2. Peta potensi wilayah pengembangan tanaman manggis di Kecamatan Pauh.

\section{Ucapan Terima Kasih}

Ucapan terimakasih diberikan kepada Kemenristekdikti yang telah mendanai penelitian ini secara penuh dalam program PKM-Penelitian pada Tahun 2018.

\section{Daftar Pustaka}

Badan Pusat Statistik. 2017. Kecamatan Pauh dalam Angka 2017. BPS. Padang. 75 hal.

Djaenuddin, D., Marwan, H., Subagjo, H. dan A. Hidayat. 2011. Petunjuk Teknis Lahan untuk Komoditas Pertanian. Balai Besar Litbang Sumberdaya Lahan Pertanian. Bogor. 36 hal.

Emalinda, Oktanis, Husin, E.F. dan Rini, D.P. 2005. Perubahan hara dan mikroorganisme pada Ultisol akibat kascing yang berbeda. Jurnal Solum 2(2): $55-61$.

Fiantis, D. 2015. Morfologi dan Klasifikasi Tanah. Universitas Andalas. Padang. 264 hal.

Hakim, N., Nyakpa, M.Y., Lubis, A.M., Nugroho, S.G., Diha, M.A., Hong, G.B. dan Bailey, H.H. 1986. Dasar-Dasar Ilmu Tanah. Universitas Lampung. Lampung. 488 hal.

Hardjowigeno, S. 2010. Ilmu Tanah. Akademika Pressindo. Jakarta. 288 hal.
Hermansah, Juniarti, dan Pribadi, U.M. 2008. Evaluasi terhadap perubahan status beberapa hara tanah setelah 10 tahun di Bukit Gajabuih Padang. Jurnal Solum 5(1): 23 - 42.

Hermon, Dedi dan Triyatno. 2005. Analisis Spatial Bahaya dan Risiko Longsor Lahan di Gunung Padang Sumatera Barat. Laporan Penelitian No. Kontrak 872/J41/KU/DIPA/2005 Tanggal 2 Mei 2005, Universitas Negeri Padang.

Nurdin. 2012. Kombinasi teknik konservasi tanah dan pengaruhnya terhadap hasil jagung dan erosi tanah pada lahan kering di Sub DAS Biyonga Kabupaten Gorontalo. Jurnal Teknik Lingkungan 13(3): 245 - 252.

Prasetyo, B.H., Subardja, D. dan Kaslan, B. 2005. Ultisols bahan volkan andesitik: diferensiasi potensi kesuburan dan pengelolannya. Jurnal Tanah dan Iklim 23: 1 - 12.

Putra, I. dan Jalil, M. 2015. Pengaruh bahan organik terhadap beberapa sifat kimia tanah pada lahan kering masam. Jurnal Agrotek Lestari 1(1): 27 34.

Rayes, L. 2007. Metode Inventarisasi Sumber Daya Lahan. CV Andi. Yogyakarta. 299 hal.

Sastrohartono, H. 2011. Evaluasi Kesesuaian Lahan untuk Perkebunan dengan Aplikasi Extensi Artificil Neural Network (Ann. Avx) dalam Arview-GIS. 
Jurnal Tanah dan Sumberdaya Lahan Vol 8 No 2: 317-326, 2021

e-ISSN:2549-9793, doi: 10.21776/ub.jts1.2021.008.2.2

Fakultas Teknologi Pertanian Institut Pertanian Stiper. Yogyakarta.

Sitorus, S. 1989. Evaluasi Sumber Daya Lahan. Tarsito. Bandung. 185 hal.
Sposito, G. 2010. The Chemistry of Soil. Oxford University. Amerika Serikat. 272 hal.

Stevenson, F.T. 1994. Humus Chemistry. John Wiley and Sons. New York. 512 hal. 